World Lumen Congress 2021 | May 26-30, 2021 | lasi, Romania

\title{
The Philosophical Vision of Legal Punishment
}

\author{
Virginia ZAHARIA, Veronica POZNEACOVA
}

https://doi.org/10.18662/wlc2021/73

How to cite: Zaharia, V., \& Pozneacova, V. (2021). The Philosophical Vision of Legal Punishment. In A. Sandu (vol. ed.), Lumen Proceedings: Vol. 17 World Lumen Congress 2021 (pp. 723-736). Iasi, Romania: LUMEN Publishing House. https://doi.org/10.18662/wlc2021/73 


\title{
The Philosophical Vision of Legal Punishment
}

\author{
Virginia ZAHARIA1, Veronica POZNEACOVA²
}

\begin{abstract}
The concept of punishment represents one of the most difficult legal issues that are related to the concept of buman freedom and responsibility. Since Antiquity, the brilliant minds of humanity contemplated about the sense of punishment and the function of this institution. Each epoch analyses this concept from different aspects and some of them are reflected in the actual legislation. The most important principles of contemporary criminal law were expounded by the Ancient, Modern and Contemporary philosophers. The field of research of this article is the philosophy of punishment of criminal law. In this study, we have applied the method of historical research of the proposed topic, which gives us the opportunity to analyze the development of criminal punishment and its goals from a historical perspective. In this paper, we aimed to determine the philosophical base of the legal punishment that legitimizes the application of sanctions to the person who committed the crime. We established the importance of the theories developed by brilliant thinkers for the contemporary concept of penal retribution and legal regulation of this institution. This theme generates several discussions that are formed in the process of comparison and debating of the ideas of influential philosophers regarding the purpose of criminal punishment. Therefore, we consider that the analysis of the theories of great thinkers gives us the possibility to understand the complexity of the phenomenon of criminal punishment, and leads to the more effective application of state constraint towards the offender.
\end{abstract}

Keywords: Crime; punishment; re-education; criminal; philosophy.

\section{Introduction}

Traditionally the institution of punishment is considered one of the most complex institutions of law, the understanding of which is possible through the prism of philosophical concepts, which help us determine the theoretical purpose, as well as the practical content of this institution. The concept of punishment was analyzed by the brilliant minds of humanity, which legitimate the application of state constraint to persons who violate the state's laws. Some of these theories represent the philosophical base of the actual penal legislation. Each epoch analyses

\footnotetext{
${ }^{1}$ PhD., Trade Co-operative University of Moldova, Faculty of Law, Department of Law, Chisinau, Republic of Moldova. e-mail: virginica.zaharia@yahoo.com

2 3rd year student, Moldova State University, Faculty of Law, Chisinau, Republic of Moldova. e-mail: veronicapozneacova@gmail.com
} 
institution of punishment from different aspects and some of them are reflected in the actual regulation. The most important principles of contemporary criminal law were expounded by the Ancient philosophers such as Plato and Aristotle (1981). Other concepts of criminal punishment were elaborated in the modern epoch, for example, the importance of unpaid work in the process of re-education of the criminal. We would pay attention to the conversation through the ages between the philosophers of Antiquity, Modernity and Contemporaneity about the most important reasons for criminal prosecution. Some of them stated that the punishment should be applied only because a person committed a crime and could not have another goal. This position generates many controversies because a group of thinkers claimed that a crime represents the act that has happened in the past and the mere commission of the crime does not legitimize the application of criminal punishment. According to these philosophers, the person should be punished for committing a crime to prevent the person to commit new offences. In this study we would analyze the specific aspects of the philosopher's theories related to the concept of legal punishment and would determine the positive and the negative aspects of their studies.

\section{Theoretical Background}

In this chapter, we would analyze the most important ideas of influential thinkers related to the concept of retribution. The topic of punishment, closely associated with that of judgement, is a recurrent motive in Plato's dialogues, repeatedly pervading various contexts with significant legislative, judicial, rhetorical, ethical and educational overtones (Konrádová, 2019). Namely Plato developed and promoted the principle of the individualization of the criminal punishment. The great thinker considered that the punishment should be appropriate to the nature of the offence, the reasons and the circumstances of the commission of the crime such as the commission of treason, of crime with particular cruelty or because of the young age. In addition, Plato notes the personal nature of criminal punishment, which should not be applied to the relatives of the criminal, even in the event of an attack on the state order (Yelchanikova, 2011). In his works, Plato formulated the principle of the inevitability of criminal punishment, which is applied by current legislation. In his early writings, Plato argued that punishment is a blessing for the offender, because it helps to restore harmony in the soul of the criminal. So, one of the primary purposes of the application of criminal punishment is the re-education of the person, who should become better after the applying of the punishment (Plato, 2008).

The importance of Plato's ideas in the actual concept of penal punishment manifests in the foundation of the basic principles of criminal law, such as the principle of the individualization of criminal responsibility and punishment. We could deduce this principle from the application of different penalties for homicide. Another basic idea of this philosopher that is common for actual legislation is the principle of personal responsibility of the offender for his crime. According to Plato, the criminal liability should be subjective. Thinker defined the involuntary 
and violence crimes, which are currently known as the crimes committed with intent or carelessness. The great thinker considered that the major purpose of the criminal punishment is the re-education of the offender, whose personal qualities after the application of punishment should be better than before it. Philosopher considered that the state should apply the penal punishment for the restoring social equity that was violated by committing a crime. So, Plato founded the concept of criminal punishment that should determine the rehabilitation of a criminal. The negative aspects of this doctrine follows from the consideration that criminals should be treated as blameless patients. In this context, philosopher do not pay attention to the moral guilt of the person, who committed the crime and do not analize the necessity to punish him for the evil he did (Howard, 2016). At the same time, the positive aspects of Plato's theory are manifested in the humanism towards the criminal and the awareness of the necessity of his integration into society. We should note that Plato's vision is essential to the entire system of criminal law, and the principles elaborated by the great thinker could be found in majority of the world's penal laws.

Another great thinker of Antiquity, Aristotle was not interested in the studying of the concept of penal punishment. However, thinker formulated the concept of formal, material, and effective causes that leads to the commission of the crime. According to the thinker's vision, the commission of the criminal act represents the expression of the person's intention, which leads to the achievement of the proposed goal (Soktoev, 2014). Thinker analyzed the character traits which should ground criminal liability, that represent the constitute vices embodied in a distorted or ethically mistaken conception of the good. We should note that the Aristotelian vice is more than wrong action, such action is partly constitutive of the relevant character trait (Duff, 2002). Later criminologists developed the free will theory based on the concept of commission of the crime as the expression of the will of the perpetrator and the causes that determine the person to resort to the criminal act. The Aristotle's theory is very important in the actual criminal law in the aspects related to the necessity of establishing the real will of the person committing the crime. This criterion should be analyzed in the process of individualization of criminal punishment (Aristotle, 1908).

The significance of Aristotle's vision within the framework of current criminal law is manifested in the argumentation of the concept of subjective liability. According to the philosopher's point of view, the person cannot be prosecuted for committing the crime if he was forced to commit the act prohibited by criminal law. So, the person could be punished if only the commission of the crime represents the expression of the offender's desire. The thinker elaborated the concept known in the contemporary criminal law as the force majeure, according to which the person cannot be convicted of causing harm that did not depend on his actions and will. In addition, the philosopher founded the concept of general prevention, which is achieved through the application of punishment, as well as a special prevention, which should convince a person who previously committed the crime not to commit other criminal acts in the future. Aristotle considered that the person can be 
persuaded not to commit crimes because of fear to be punished. Aristotle substantiated the concept of causes that remove the criminal character of the act, for example, physical and/or mental constraint or extreme necessity. So, we should note that thinker formulated the most important categories and notions which represent the basic concepts of criminal law in contemporary epoch.

Analyzing the development of penal punishment, we should mention that in the Middle Ages, the religious vision of the most important issues of people's life dominated the thinking of humanity. In that period, the church elaborated the concept of punishment, according to its official position. We should note that in the Middle Ages, secular theories were not developed.

Plus, we should mention that one of the major purposes of punishment was proclaimed the salvation of the person's soul by applying the righteous and merciful punishment. From the one point of view, in the Middle Ages the punishment became more humane than before, because a Christian should not be sentenced to death (Robertson, 1925. Pp, 174-177). On the other hand, society was dominated by the pessimism and expectation of the Antichrist. These considerations form the concept according to which is impossible to re-educate the offender without the application of corporal punishment. In the middle of the twelfth century, the intimidation function of legal punishment was the dominant one.

In this period was developed the concept of religious revenge, according to which the right to punish has a divine origin. The right to punish takes on a mystical character emanating from heaven. The crime damages to divinity, and to the order established by it, so the offender should be punished in order to fulfill the divinity (Ciobanu, 2007, pp. 132-133). This theory was developed by Tertullian, Saint

\section{Augustine, Selden, Jozef de Maistre.}

The modern era is characteristic by another vision of the concept of criminal punishment. This epoch includes the period between the sixteenth and the beginning of the twentieth century. The Renaissance period is characterized by the secular development of science and culture, by the triumph of the ideas of humanism, the regulation of human rights in the French Declaration of human and citizen rights (1789), the appearance of the first written constitutions such as the US (1787) and the French Constitutions. The philosophy in this period, it is dominated by several currents including the materialism, and the justification of absolute monarchy created by Thomas Hobbes, humanism, promoted by philosophers of French revolution such as Montesquieu, Rousseau, Voltaire, John Locke, German idealism, formulated by Immanuel Kant and developed by Georg Hegel, followed by the justification and promotion of the pessimist doctrine of Arthur Schopenhauer, concluded by the philosophy of Friedrich Nietzsche.

One of the most important thinkers of the Modern Epoch is Thomas More. In this work, the philosopher created the model of the state which has some character theaters of the communist city-state. This state, its institutions and programs are completely governed by reason. We could note the significant difference between the order of the ideal utopic state construction and the Christian Europe's reality. Thomas More described the politics of Europe of that time in the Book I dating 
1516. In this book Europe is presented as divided by self-interest and greed for power and riches. The main character of this work, Raphael Hythloday, is the traveler which states that the communism is the only one form of government that could diminish the negative aspects of social life such as egoism in private and public life. The performing demonstration of his literacy, ingenuity, and wit established his character as one of the foremost humanists (Marc'hadour, 2021).

The importance of the great thinker's theory is the actual legislation manifests by establishing of the influence of the country's economic and social situation on criminal behavior. On the one hand, society condemns criminals to combat the criminality, and, on the other hand, it creates the prerequisites for the development of criminality. The state fights with criminals, but not with the causes that lead people to resort to criminal behavior. Thomas More elaborated the concept knowing in the actual criminal law as unpaid community service. The thinker argued the necessity of the individualization of criminal punishment, as well as the creation of a system of punishments, stating that this system should be graded depending on the seriousness of the illegal act (More, 2000).

H. Grotius and T. Hobbes developed the theoretical argumentation of the law of the Talion and the concept of retributive punishment. H. Grotius in his work "De Iure Belli ac Pacis" analyzes the concept of punishment in the context of the 'just war' and 'solemn war'. Thinker considered that punishment during the war has the specific role that goes beyond one of the just causes of war. Grotius remarked the necesity of the extension of punitive justice during the war. Thinker afirmed that the concept of privat punishment should exist because the sovereign's right to punish cames from the privat one. H. Grotius considered that acording to the natural law anyone could punish the person who borkes this law, at any rate "anyone who is not subject to vices of the same kind" as the aggressor (H. Grotius 2001 II.xx.3, p. 465, also II.xx.6). This vision determined the reconceptualization of the aggressors position that is turned into the universal criminals. Thinker positioned the right to criminal punishment as a universal good and not as the concept related to just desserts or the revenge in the victim of aggression. In chapter xx of book II of De Iure Belli ac Pacis, dedicated to the description of the theory of punishment, thinker argued the necessity of this institution from the point of view of criminal, the victim and the humanity. However, the punishment represents the good for criminal because of its function of correction and rehabilitation of offender, and as such it was inflicted for their own good (Grotius 2001II.xx.6.2). In plus, the punishment could protect the victim from renewed attacks by incapacitating the aggressor. Also, this institution could prevent new crimes and protect all potential victims of that criminal. In addition, by being exemplary, "public and conspicuous", punishment could deter all potential aggressors (Grotius, 2001, p. 472; Kalmanovitz, 2020).

The concept of criminal punishment was analyzed by Thomas Hobbes (1588-1679) the English materialist philosopher, one of the founders of modern political philosophy, of the theory of the social contract, and state sovereignty. The twenty-eighth chapter of Leviathan, titled 'Of Punishments and Rewards,' begins 
with a definition of punishment. "A Punishment, is an Evill inflicted by publique Authority, on him that hath done, or omitted that which is Judged by the same Authority to be a Transgression of the Law; to the end that the will of men may thereby the better be disposed to obedience"(Hobbes, 2002). Hobbes analyzed the origin of the right to punish. According to philosopher's point of view, this right could not be delegated to sovereign by people. Thinker argued that 'no man is supposed bound by Covenant, not to resist violence' and so he thought it was obvious that no one 'gave any right to another to lay violent hands upon his person' in the social contract. So, the right to punish could not appear as a result of the social contract. Therefore, he reasoned, it 'is manifest' that the right to punish 'is not grounded on any concession or gift from the subjects' (Green, 2016).

The existance of the punishment requires a public authority, the existence of the state. However, the sovereign's possession of the right of nature cannot fully clarify the sovereign's right to punish because it does not create the sovereign a public authority. Furthermore, Hobbes mentioned that the peoples sanction their own punishments in the social contract. From these considerations, we could mention that the sovereign's right to punish could not be natural one, or this vision is at least incomplete. In conclusion, we should mention that the right to punish could not be independent from the social contract and should, partly, derive from it (Green, 2016).

In plus, Hobbes identified three causes that lead to an increase in the criminality's level: 1) ignorance or misunderstanding of legal provisions; 2) the wrong vision which causes the committing of crime; 3) uncontrolled manifestation of feelings (Hobbes, 2002). The philosopher stated that punishment is the evil caused by state power to the person who by action or inaction committed the act considered by the state leadership as a crime. The purpose of the application of punishment is to influence the will of people so that they become more obedient.

The Hobbes's concept of punishment influenced the development of criminal law in the natural law tradition. Thinker is one of the foundations of the secular theory of state power, which contradicts to the theological state construction. Hobbes's systematic distinction between divine and earthly justice has been fundamental for the secularization of penal law in particular (Hobbes, 2002, pp. 186-187; 235-236). Hobbes introduced the concept of punished and unpunished offenses. The external acts are included in the punishable offences, while all internal acts (opinions or beliefs) are not punishable. So, from these considerations we could conclude that religious, ideological or political opinions could not be the object of coercive legal force (Hüning, 2007).

Therefore, the importance of the concept of Hobbes in contemporary criminal law is manifested by the foundation and development of the principle of legality. According to the thinker, criminal punishment should be applied only by the court. Hobbes formulated the principle of non-retroactivity of the law, because the legislative act cannot be violated until its publication. In addition, the philosopher substantiated the principle nulla poena sine lege, stating that it could not be applied a harsher penalty than that provided for by the legislation. The purpose of punishment, in the thinker's point of view, is the re-education of the 
offender and the general and special Prevention. Hobbes substantiated the concept of individualization of criminal punishment, analyzing the personality of the offender and the specifics of the crime committed.

The British philosopher William Paley (1734-1805) supported a utilitarian view of morality. The importance of the concept of Paley's utilitarianism manifests in the fact that in is the base of the classical liberalism as the Enlightenment's political ideology. However, some aspects of his doctrine correspond to the aristocratic paternalism of the XVIII century, the movement that contravenes to liberalism. Paley supported the concept of inequalities of the distribution of property; he condemned the slave trade; he proposed a graduated income tax (Le Mahieu, 2002).

The thinker considered that the major purpose of punishment is to prevent the commission of subsequent offenses, denying the retributive function of a punishment. The main purpose of punishment is to prevent the general and special prevention of subsequent offenses. The whole concept of punishment, in the William Paley's vision, is focused on the likelihood of resorting to criminal behavior of the person who previously committed the crime or other persons. The punishment should be determined depending on the complexity of the crime committed and the need to prevent the commission of a similar crime. However, the punishment should not be severe if the commission of this crime could be prevented by other means. William Paley was one of the first thinkers who argued the expediency of using inmate labor to achieve a positive effect. In particular, the philosopher pointed out that the unwillingness to work causes several human vices. Therefore, in the process of determining the sentence, the court must consider this aspect (Paley, 1825). The thinker argued the necessity of prohibition of corporal punishments and public capital punishments, because witnessing such events makes people crueler. In his work philosopher stated the need to establish the proportionality between the intimidating degree of punishment, the dangerousness of the crime for society and the likelihood of committing a similar crime. In addition, William Paley was one of the first thinkers who proposed the development of programs for re-socializing people after serving their sentence (Paley, 1825).

The importance and actuality of the ideas of William Paley is manifested by arguing the application of punishment for general and special prevention purposes, the elaborating the concept of unlisted community service, as well as the expediency of implementation of programs aimed at the resocialization of former convicts.

One of the most influential philosophers of modernity, Immanuel Kant (1724-1804) considered that the foundation of criminal punishment is absolute justice, which demands the reward of good and the punishment of evil (Ciobanu, 2007, p. 133). Kant is one of the brilliants representative of the retributivist theory in the philosophy of punishment. Thinker analyzes this concept both through the criminal's guilty for the crime and the retribution for this act. However, the punishment is justified only if the person is guilty in the commission of the crime. The negative aspects of the uses of punishment, such as rehabilitation (the alleged good of the criminal) or deterrence (alleged well to society) uses the criminal merely 
as a means (6:331). The punishment could be useful only after the determination of the person's guilt. In the Feyerabend lectures on Natural Right, Kant is clear that the sovereign "must punish in order to obtain security", and even while using the law of retribution, "in such a way the best security is obtained" (27:1390-91).

The state is authorized to use its coercive force to defend freedom against limitations to freedom; more particularly, since right does not entail that citizens must limit their own freedom but only that "freedom is limited" by conditions of right, it is right for another, i.e. the state, to actively limit citizens' freedom in accord with right $(6: 231)$. The state is authorized to use force to defend property rights (6:256). According to thinker's point of view, the punishment could have the deterrent functions in relation to a certain person. However, this function could not be the base of the institution of punishment (Rauscher, 2021).

According to the retributivist theory for the punishment it is necessary the finding of person's guilty. However, the appropriate type and amount of punishment is determined by the crime itself. Traditionally this is the heart of the ancient injunction "an eye for an eye". Kant supports this measurement for punishment because all other measurements bring into consideration elements besides strict justice (6:332), such as the psychological states of others that would measure the effectiveness of various possible punishments on deterrence. As a principle, retribution grounds but does not specify the exact punishment. Kant recognizes that "like for like" is not always possible to the letter, but believes that justice requires that it be used as the principle for specific judgments of punishment. The retributivist theory of punishment leads to Kant's insistence on capital punishment. He argues that the only punishment possibly equivalent to death, the amount of inflicted harm, is death. Death is qualitatively different from any kind of life, so no substitute could be found that would equal death (Rauscher, 2021).

We should note that the philosopher defined criminal law as the right to apply punishment. According to his doctrine, this right represents the infliction of suffering to the person who committed the crime. The punishment should be applied, because it was committed a crime according to the law of absolute justice. Philosopher considered that justice is violated by offense, thus punishment (and criminal law) is a categorical imperative. So, the application of criminal punishment should not have another justification and purpose. (Ciobanu, 2007, p. 133). From those exposed above, we can conclude that the purpose of applying criminal punishment, according to Kant, is the achievement of abstract (universal) justice. Philosopher argued that the only reasonable theory of punishment was the retributive one, which is based on the Talion principle and material retribution (Voronkova, 2014). Kant considered that the relationship between crime and punishment should be equal. The state in applying the punishment should inflict to the offender equal or equivalent moral or material harm as that inflicted to the victim by the crime (Ciobanu, 2007, p. 133). Punishment is the just retribution of committed evil and embodies the purpose itself because it was committed a crime. Punishment is the goal and not the mean or tool useful to society. It cannot be applied for obtaining another good, because this approach means treating a man as 
a thing, using him as an instrument, which would be incompatible with his personality and moral dignity (Ciobanu, 2007, p. 133). The importance of the Kant's concept in the current legislation is manifested in the formulation of the principle of subjectivity of responsibility, because only the person who committed the act with guilt may be held criminally liable (Kant, 1965).

Georg Hegel (1770-1831) the great German philosopher, the founder of the dialectical method of thinking, considered law to be an absolute notion. Hegel propounds his theory of punishment primarily in his Philosophy of Right, where punishment is treated at the end of the first part, entitled "Abstract Right." As its title implies, "Abstract Right" considers rights--and humans--not in their fullness but abstractly. The human actors in "Abstract Right" are persons, which for Hegel is a technical term: a person is but an abstraction from man. In the opening sections of "Abstract Right," persons claim property and make contracts. In the third section, "Wrong," a person wants something which is already owned as property but does not want to obtain it by making a fair contract involving goods of equal value. The person, therefore, just takes the property, or hits the other person, in violation of the other's fights. This is crime, where the criminal negates the victim's right to the particular property stolen and also denies the victim's capacity for rights in general by depriving him forcibly of a property which embodies his rights and freedom. Crime involves the coercing of the innocent person's will and therefore the denial (or negation) of the freedom and fights of the victim's will. The will can be coerced simply because it exists in property in order to manifest its freedom; in crime, the victim's will, coerced, is deprived of the embodiment of its freedom (91). On the level of fights, then, crime is a denial of rights and in effect an attempt to negate rights (Stillman, 1976).

We should note that the offense is the denial of the absolute and inviolable right, and the punishment consists in the process of annulment of the denial of the right; thus the punishment is the denial of the denial of the right. As strong as the unjust denial is, so strong must be the just denial, the statement contained in the punishment. Hegel considered that justice is the foundation of the right to punish. However, usefulness may be one of the potential effects of punishment, but not its foundation (Pop, 1928, p. 200) Thinker substantiated the concept of retributive punishment that is a right of the criminal.

However, Hegel is aware that few criminals consciously commit crime in order to deny the rights of others. A person who is very hungry may steal from a rich person, not in order to deny that rich person's rights, but in order to survive. But intentions and particular circumstances have no relevance in terms of abstract rights. The "true and right factor" must relate not to intentions or particularity but to the will and to rights; what matters is the will of the criminal person denying the rights of the victim (Stillman, 1976).

Hegel interpreted the idea of law as the individual's freedom. Based on this interpretation, the crime represents an expression of the will of the offender, which denies the existing order of law. The criminal, by committing the crime, consents to the application of the punishment, which arises as a result of the manifestation of 
the criminal's freedom (Hegel, 1934, pp. 147-148). The criminal recognizes the existence of law and order of law by committing the deviant act. It follows that the offender can be held criminally liable under the law he has recognized (Hegel, 1934, p. 149). Hegel interprets the concept of punishment as retribution, which is manifested in the restoration of the violated order of law. We should note that the concept of retributive punishment in Hegel's point of view differs from the concept of his predecessors because it is not a pure retribution, but the restoration of the order of law violated by the offender.

Arthur Schopenhauer, the German philosopher, distinguished between the concept of revenge and that of punishment. Punishment, in the thinker's view, always has a moral justification, but revenge is devoid of such justification, since retribution with an evil for the evil committed is meaningless. Schopenhauer's theory is not original and draws its origins from previous philosophical and legal concepts (Plato, Hobbes, Pufendorf) (Sehaefer, 1982). Schopenhauer stated that he agreed with some aspects of the theory of punishment developed by his predecessors. Particularly important in the context of contemporary criminal law is the Schopenhauer's vision on the concept of criminal punishment, because the philosopher stated that the basis of criminal law should be the principle that punishment is applied not to the person, but to the illegal act. So, the crime is condemned by society. The criminal in this point of view is the "material" by which the crime is punished and condemned. The purpose of punishment, in Schopenhauer's vision, is the intimidation of the crime.

Schopenhauer denied the concept known in the current doctrine of criminal law as mitigating circumstances, stating that despite of the major influence of ignorance and material needs on the offender these circumstances cannot play a determined role in the formation of criminal intent, because most people, who live in similar conditions do not commit criminal acts. So, the basic role in the formation of criminal intent plays personal experience and the character of the criminal, which does not change. Thinker considered that the correction of the offender and his re-education is impossible, and the criminal's behavior could be influenced only by intimidation (Schopenhauer, pp. 161-162).

Schopenhauer argued that punishment should be proportionate to the gravity of the crime committed, stating that the application of the death penalty is necessary for murder or attempted murder. The philosopher considered that the person is punished for his action, without considering the prejudicial aftermath of the committed act. Schopenhauer noted that punishment should be equal to the prejudicial consequences (Schopenhauer, pp. 161-162).

The importance of Schopenhauer's theory is manifested in the regulation in the Penal Code of the Republic of Moldova of the state of recidivism. According to the Penal Code of 1961 the person was qualified as a recidivist, but according to contemporary legislation the crime is committed in the state of recidivism, the qualification attributed to the act, not to the personality of the offender.

Friedrich Nietzsche (1844-1900) the German classical philosopher claimed that the concept of law does not exist, for the point of view of lust for 
power. In a conflict between 2 people's wills, the one wins and, as a result, the winner raises his will to the rank of law. Therefore, law and justice belong to the strong one.

Nietzsche did not support the concept of punishment, but that of repression. For him, the crime represents a revolt against the social order and highlights the social's problem. If this uprising is a mass one, then the people who support it should be decorated. However, one-person's uprising must be sanctioned with the application of the prison sentence. The offender is a powerful personality, who risks with everything: life, dignity and freedom. Nietzsche considered that the existence of the criminal punishment represents the self-defense of society, being a right of the weak, of that people who cannot defend themselves and need the support of the state.

In the work "Thus Spoke Zarathustra" the finality, the apogee of the crime is seen by Nietzsche in the self-condemnation of the criminal, for whom death is the salvation, because he suffers from torments of conscience. The application of capital punishment in this case is seen as a rescue of the offender from moral torments and should be applied because of mercy and compassion, not because of revenge. On the one hand, the commission of the crime represents the natural impulse, which comes from the power and thirst for a life of man. On the other hand, after the commission of the crime the offender cannot bear remorse, because the person no longer positions himself as "man", but as "offender", which gives rise to madness (Nietzsche, 2010).

Nietzsche does not deny the concept of criminal punishment, but emphasizes the internal remorse of the person. From the punishment imposed by the court the person can be released, but moral punishment is present throughout the life of the offender. There is no possibility to re-educate him, to reduce the damages caused or to restore the violated public order. Moral punishment is a permanent one, it does not change. This is a natural sanction that must be endured by the criminal throughout his life. Starting from this hypothesis, Nietzsche stated that the only salvation, which would allow the person not to endure the remorse of conscience is capital punishment, which is "milder", than the continuous awareness of the weight of the committed crime. Therefore, punishment represents the liberation, it is applied out of pity.

According to Nietzsche, the whole institution of punishment is based on faith in punishment, because is considered that punishment awakens in the offender the feeling of guilt and remorse. Nietzsche denied that view because he considered that criminals rarely feel true guilt and remorse. In addition, general observations of the practice of applying punishment show that it strengthens the resistance of the offender, leads to his concentration, makes him feel isolation from society. The thinker considered that the application of punishment stops the appearance of the feeling of guilt, because the judgement process and the application of punishment deprive the offender of the possibility of awareness of the prejudicial degree of the committed act. So, the application of punishment leads to the fact that the person becomes more attentive to the commission of the crime, more self-critical, 
overwhelmed with distrust in the future. Respectively, punishment makes a person more lenient, but it does not make him better (Nietzsche, 2007).

We should note that Nietzsche considered that the application of punishment cannot lead to the achievement of the proposed aims, because it makes a person more violent. Nietzsche's theory shows the ineffectiveness of the application of criminal punishment.

\section{Arguments}

The importance of this research lies in the fact that currently the issues related to the philosophy of criminal punishment remain poorly studied. In our days, the majority of the researches are focused on the studying of the principles of criminal law without analyzing the history of the formation and crystallization of these principles. Thus, in this research, we would like to analyze the importance of the philosophers' theories in modern criminal law, and we believe that this article will help to reduce the necessity of researches in this area. Thus, we have established both the main ideas of philosophers about punishment, and the applicability of the principles of modern criminal law in the actual legal regulation.

\section{Conclusions}

In conclusion, we can claim that the actual concept of penal punishment was formed and developed by the most influential thinkers of the humanity. However, the purposes of criminal punishment, regulated by the contemporaneous legislation, represent the development of the theories of Ancient Greece's thinkers Plato and Aristotle. The evolution of these thinker's ideas is manifested in the purposes of criminal punishment in the current legislation, such as the re-education of criminal, general and special prevention and the restoring of social equity. So, we can conclude that the philosophical development of the concept of legal punishment is essential for the actual penal legislation, in general, and the applicability of the institution of punishment, in particular.

\section{References}

Aristotle, \& Ross, W. D. (1981). Aristotle's Metaphysics. Oxford

Ciobanu, I. (2007). Criminologie [Criminology]. Reclama Publishing House.

Duff, R. (2002). Virtue, Vice, and Criminal Liability: Do We Want an Aristotelian Criminal Law. Buffalo Criminal Law Review, 6(1), 147-184. http://dx.doi.org/10.1525/nclr.2002.6.1.147

Green, M. J. (2016). Authorization and the Right to Punish in Hobbes. Pacific Pbilosophical Quarterly, 97(1), 113-139. https://doi.org/10.1111/papq.12097

Grotius, H. (2001). On the law of war and peace. Batoche Books Kitchener.

Hegel, G. V. F. (1934). Philosophy of law. Sotsekgiz.

Hobbes, T. (2002). Leviathan. Wordsworth 
Höffe, O. (1999). Metaphysische Anfangsgrunde der Rechtslehre. Kant's Gesammelte Schriften [Metaphysical foundations of legal theory. Kant's Collected Writings]. Walter de Gruyter.

Howard, J. (2017). Punishment as Moral Fortification. Law and Philosophy, 36, 45-75. https://doi.org/10.1007/s10982-016-9272-2

Hüning, D. (2007). Hobbes on the Right to Punish. In P. Springborg (Ed.), The Cambridge Companion to Hobbes's Leviathan (pp. 217-240). Cambridge University Press. https://doi.org/10.1017/CCOL0521836670.010

Kalmanovitz, P. (2020). The Laws of War in International Thought. Oxford University Press.

Kant, I. (1965). Metaphysics of morals. Cambridge University Press.

Konradova, V. (2019). The Concept of Punishment in Plato's Eschatological Myths. Etica e Politica, 3, 571-582. http://www2.units.it/etica/2019 3/KONRADOVA.pdf

Le Mahieu, D. L. (2002). Introduction to Paley's The Principles of Moral and Political Philosop. Liberty Fund.

Marc'hadour, G. P. (2021). Thomas More. Encyclopedia Britannica.

More, T. (2000). Utopia. CreateSpace Independent Publishing Platform.

Nietzsche, F. (2007). On the Genealogy of Morality. Cambridge University Press.

Nietzsche, F. (2010). Thus Spoke Zarathustra. Dover Publications.

Paley, W. (1825). The principles of moral and political philosophy. Liberty Fund Inc.

Plato. (2008). Laws. Cambridge University Press.

Pop, T. (1928). Curs de criminology [Criminology course]. Universul Juridic Publishing House.

Rauscher, F. (2021). Kant's Social and Political Philosophy. The Stanford Encyclopedia of Philosophy.

Robertson, A. J. (1925). The Laws of the Kings of England from Edmund and Henry. Cambridge University Press.

Schopenhauer, A. (1997). Selected works. Rostov

Sehaefer A., (1982). Die Schopenhaner. Berlin Verlag.

Soktoev, Z. (2014). Aristotle's Philosophy and Criminal Law Causality, Legal Sciences Actual Problems of Criminal Law and Criminology. Bulletin of the Moscow University of the Ministry of Internal Affairs of Russia, 1.

https://cyberleninka.ru/article/n/filosofiya-aristotelya-i-ugolovno-pravovayaprichinnost

The Gouvernament of United States. (1787). The Constitution of the United States (1787). The constitutional Convention. https://www.ourdocuments.gov/doc.php?flash=false\&doc $=9$

The Gouvernament of United States. (1789). The Constitution Of The United States Bill of Rights \& All Amendments. Congress of the United States. https://www.archives.gov/founding-docs/bill-of-rights-transcript

The National Assembly of France. (1789). The French Declaration of the Rights of Man and Citizen. The National Assembly of France. https://avalon.law.yale.edu/18th century/rightsof.asp 
The National Assembly. (1971). The Constitution of 1791 National Assembly September 3, 1791. National Assembly. https://wp.stu.ca/worldhistory/wpcontent/uploads/sites/4/2015/07/French-Constitution-of-1791.pdf

Voronkova, N. V. (2014). Philosophical and legal teachings on punishment in the XV-XVIII centuries. Novosibirsk State Technical University.

Yelchanikova, O. (2011). K voprosu o vzglyadakh Platona na instituty «Prestupleniye» i «Nakazaniye» [On the question of Plato's views on the Institutions of "Crime" and "Punishment"]. Actual problems of the theory and history of state and law. Vestnik Samarskogo yuridicheskogo instituta [Bulletin of the Samara Law Institute], 2, 13-18. https://cyberleninka.ru/article/n/k-voprosu-o-vzglyadah-platona-na-institutyprestuplenie-i-nakazanie 